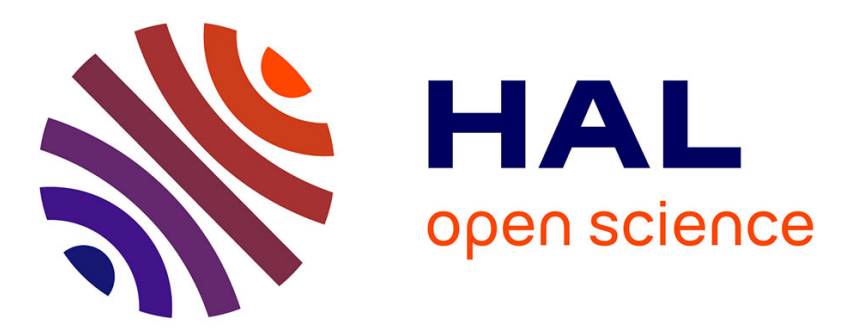

\title{
Middle to Late Miocene Eccentricity Forcing on Lake Expansion in NE Tibet
}

\author{
Zhixiang Wang, Chunju Huang, Alexis Licht, Rui Zhang, David B Kemp
}

\section{To cite this version:}

Zhixiang Wang, Chunju Huang, Alexis Licht, Rui Zhang, David B Kemp. Middle to Late Miocene Eccentricity Forcing on Lake Expansion in NE Tibet. Geophysical Research Letters, 2019, 46, pp.6926 - 6935. 10.1029/2019gl082283. hal-03469361

\section{HAL Id: hal-03469361 https://hal.science/hal-03469361}

Submitted on 7 Dec 2021

HAL is a multi-disciplinary open access archive for the deposit and dissemination of scientific research documents, whether they are published or not. The documents may come from teaching and research institutions in France or abroad, or from public or private research centers.
L'archive ouverte pluridisciplinaire HAL, est destinée au dépôt et à la diffusion de documents scientifiques de niveau recherche, publiés ou non, émanant des établissements d'enseignement et de recherche français ou étrangers, des laboratoires publics ou privés. 


\section{Geophysical Research Letters}

\author{
RESEARCH LETTER \\ 10.1029/2019GL082283 \\ Key Points: \\ - Regional lake expansion cycles have \\ been consistently dominated by \\ 100-kyr eccentricity forcing over \\ most of the middle to late Miocene \\ - These $100 \mathrm{kyr}$ cycles corroborate \\ with a significant forcing of the East \\ Asian hydrological cycle by \\ Antarctic ice sheet variations \\ - This study emphasizes the existence \\ of a strong teleconnection between \\ Antarctic ice sheet modulations and \\ the continental climate of Asia
}

Supporting Information:

- Supporting Information S1

Correspondence to:

C. Huang,

huangcj@cug.edu.cn

Citation:

Wang, Z., Huang, C., Licht, A., Zhang, R., \& Kemp, D. B. (2019). Middle to late Miocene eccentricity forcing on lake expansion in NE Tibet. Geophysical Research Letters, 46, 6926-6935. https:// doi.org/10.1029/2019GL082283

Received 31 JAN 2019

Accepted 30 MAY 2019

Accepted article online 5 JUN 2019

Published online 24 JUN 2019

(C)2019. American Geophysical Union. All Rights Reserved.

\section{Middle to Late Miocene Eccentricity Forcing on Lake Expansion in NE Tibet}

\author{
Zhixiang Wang1 ${ }^{1}$, Chunju Huang ${ }^{1,2}\left(\mathbb{D}\right.$, Alexis Licht ${ }^{3}$, Rui Zhang', and David B. Kemp ${ }^{1}$ \\ ${ }^{1}$ State Key Laboratory of Biogeology and Environmental Geology, School of Earth Sciences, China University of \\ Geosciences, Wuhan, China, ${ }^{2}$ Hubei Key Laboratory of Critical Zone Evolution, School of Earth Sciences, China \\ University of Geosciences, Wuhan, China, ${ }^{3}$ Department of Earth and Space Sciences, University of Washington, Seattle, \\ WA, USA
}

Abstract The East Asian summer monsoon (EASM) variability on orbital time scale has been extensively investigated in Quaternary loess and speleothems. However, EASM variability during pre-Quaternary time remains poorly understood. Here we report a continuous upper Miocene cyclostratigraphic record from lake deposits of the Tianshui basin, Northeast Tibet, to reconstruct past variations of the regional hydrological cycle. Our results, combined with previously published cyclostratigraphic records from Northeast Tibet, show that regional lake expansion cycles have been consistently dominated by $\sim 100$-kyr eccentricity forcing over most of the middle to late Miocene. These $\sim 100 \mathrm{kyr}$ cycles corroborate a significant forcing of the East Asian hydrological cycle by Antarctic ice sheet variations at that time. It is, however, unclear if this forcing affected EASM intensity or westerly derived moisture supply to the far east. Regardless of the nature of the main source of precipitation in Northeast Tibet during the Miocene, these results emphasize the existence of a strong teleconnection between Antarctic ice sheet modulations and the continental climate of Asia.

\section{Introduction}

The East Asian Summer Monsoon (EASM) is an important component of the global climate system and delivers abundant moisture from the Pacific Ocean and the South China Sea to East Asia, affecting the economic development of densely populated areas (Li et al., 2017). During the past few decades, it has attracted considerable attention from climatologists, geographers, and geologists. Reconstructing the evolution of monsoonal intensity through time is important to understand how monsoons have shaped Asian paleoenvironments and to quantitatively constrain the fundamental mechanisms driving Asian atmospheric circulation and related rainfall with the potential to provide insight into the response of Asian monsoons to future high $p \mathrm{CO} 2$ scenarios.

EASM variability on orbital time scales during the Pleistocene period is well documented from the loesspaleosol sequences of the Chinese Loess Plateau (e.g., Ding et al., 2002; Sun et al., 2006), speleothem records (e.g., Caley et al., 2011, 2014; Cheng et al., 2016; Wang et al., 2008), lacustrine deposits (e.g., Ao et al., 2012; Nakagawa et al., 2008), and marine records in the South China Sea (e.g., Ao et al., 2011). Grain size and magnetic susceptibility (MS) records from loess and fine-grained lacustrine deposits of North China show dominant obliquity cycles (41 kyr) before $\sim 0.9 \mathrm{Ma}$ and dominant eccentricity ( 100 kyr) after $\sim 0.9 \mathrm{Ma}$, consistent with benthic $\delta^{18} \mathrm{O}$ compilations (Lisiecki \& Raymo, 2005). In contrast, pedogenic $\delta^{18} \mathrm{O}$ variations in loess are dominantly forced by obliquity over most of the Pleistocene (Li et al., 2017). This discrepancy suggests that the evolution of winter monsoonal intensity-controlling dust transport-and thus grain size and MS in floodplain fines in North China-is not impacted by the same processes as the evolution of the summer monsoonal intensity controlling soil water $\delta^{18} \mathrm{O}$ values (Li et al., 2017).

In South China, $\delta^{18} \mathrm{O}$ records from stalagmites are characterized by precession ( $23 \mathrm{kyr}$ ) cyclicity over the past $1.8 \mathrm{Ma}$ (Cheng et al., 2016; Wang et al., 2008); these variations closely follow sea surface temperature (SST) changes at low latitudes (Caley et al., 2014). The discrepancy in the dominant orbital forcing between North and South China shows that the penetration of monsoonal moisture into North China is driven by mechanisms more complex than changes in the contribution of equatorial moisture sources, likely involving atmospheric teleconnections between ice sheet expansion, westerly winds intensity, and heat transfer at high latitude (Weber \& Tuenter, 2011). 


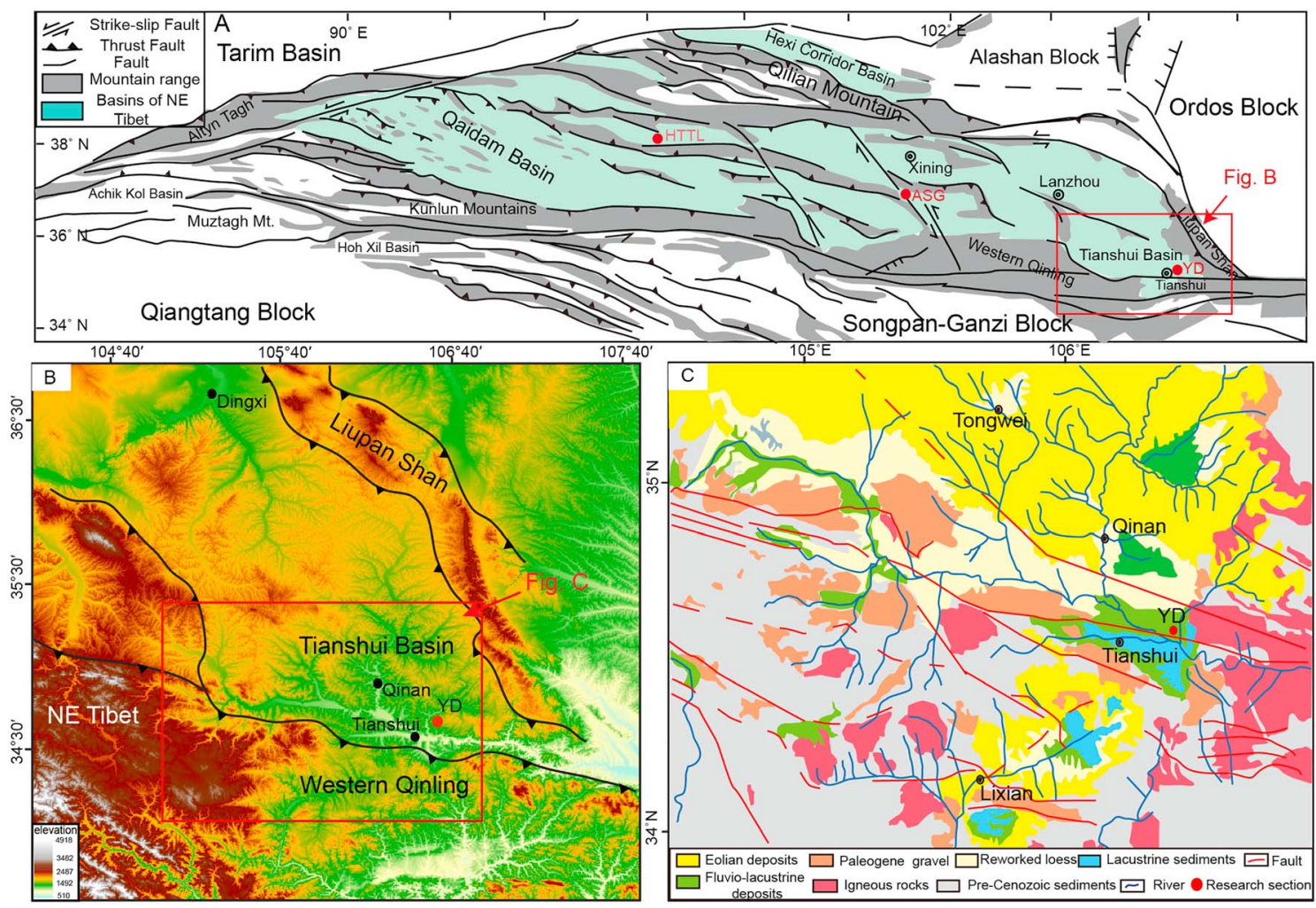

Figure 1. (a) Locations of the Tianshui Basin and tectonic setting of the northern Tibetan plateau (modified from Wang et al., 2011). HTTL $=$ Huaitoutala section in the Qaidam basin (Nie et al., 2017); ASG = Ashigong section in the Guide basin (Wang et al., 2018); YD = Yaodian section in the Tianshui basin (this study) (b) Map showing the Tianshui basin and the sampling location. (c) Lithological distribution in the Tianshui basin (modified from Wang et al., 2017).

Deciphering orbital fluctuations of lake expansion in North China in deep time could shed light on the origin of these teleconnections. Pre-Quaternary records of orbital climatic variations are unfortunately rare. In the Chinese Loess Plateau, strong 400-kyr and weak 100-kyr signals in grain size and MS have been reported for most of the Pliocene: in the Lingtai red clay section (Sun et al., 2006), in the Chaona red clay section (Nie et al., 2008), and in the Shilou section (Anwar et al., 2015). The origin of this eccentricity forcing is poorly understood and at odds with the marine record over the period (Lisiecki \& Raymo, 2005; Pollard \& DeConto, 2009). Earlier, late Miocene (8.5-7 Ma) lacustrine expansions in the Qaidam basin of North Tibet have been shown to be mainly controlled by $\sim 100$ kyr cycles (Nie et al., 2017). Similarly, middle Miocene (14-10 Ma) lake expansion in Northeast Tibet displayed cyclic variations following 100 kyr cycles and weaker $\sim 41 \mathrm{kyr}$ cycles (Wang et al., 2018). In contrast, Heitmann et al. (2017) suggested that obliquity might have been the main forcing of moisture supply during this period, though this assessment is based on a thin (12 m thick) outcrop in the Tianshui basin covering just the interval from 13.7 to $13.2 \mathrm{Ma}$.

This study aims to further document the deep time evolution of the EASM and its orbital controls by providing additional cyclostratigraphic data from Northeast Tibet and discuss their paleoclimatic implications. Specifically, we investigate the cyclicity in a 10.25 - to 8-Ma lacustrine record from the Tianshui basin, NE Tibet, previously dated by magnetostratigraphy (Li et al., 2006). This new record fills the temporal gap left between the Qaidam and Guide basin records; all together, the combination of these cyclostratigraphic records allows us to consider the controls on the North China hydrological cycle over a significant part of the middle and late Miocene.

\section{Geological Setting}

NE Tibet is today enclosed by numerous mountain ranges: The Qilian Shan to the north, the Kunlun Shan to the south, the Altyn Tagh to the west, and the Liupan Shan to the east (Lease et al., 2012; Figure 1a). This region contains numerous Cenozoic sedimentary basins, including the Qaidam, Gonghe, Xining, Guide, 
Xunhua, Linxia, Lanzhou, and Tianshui basins. Basin partitioning has been shown to be mostly Neogene in age (Lease, 2014) in response to mountain uplifts: Laji Shan (22 Ma; Lease et al., 2012), Jishi Shan (13 Ma; Lease et al., 2012), Riyue Shan (9 Ma; Lease et al., 2007); Gonghe Nan Shan (7-10 Ma; Craddock et al., 2011); Liupan Shan (8 Ma; Zheng et al., 2006); and Qinghai Nan Shan (6 Ma; Zhang et al., 2012).

The Tianshui basin is enclosed by the West Qinling Shan to the south, the Huajia Mountains to the north, and the Liupan Shan to the east (Figure 1c). Cenozoic deposits in Tianshui basin are divided into the Paleogene Guyuan Group and the Neogene Gansu Group on the basis of lithofacies and paleontology ( $\mathrm{Li}$ et al., 2006; Qu \& Cai, 1984). An unconformity between these groups can be widely observed (Li et al., 2006). The Paleogene Guyuan Group is dominated by massive conglomerates and sandstones with thicknesses varying from several tens of meters in the north to hundreds of meters in the south (Wang et al., 2017; Yuan et al., 2007). The Neogene Gansu Group includes eolian red clay-paleosol sequences, reworked loess deposits, fluvial deposits, and lacustrine deposits (Li et al., 2006; Wang et al., 2017). In this study, we investigate in detail the cyclostratigraphic record of the Yaodian section from the Gansu Group $\left(105^{\circ} 55^{\prime} \mathrm{E}\right.$, $34^{\circ} 38^{\prime} \mathrm{N}$, near Yaodian village). The section was previously dated by Li et al. (2006) using a combination of biostratigraphic and magnetostratigraphic proxies. Abundant fossil material including specimens of Hipparion weihoense, Cervavitus novorossiae, and Ictitherium so constrains the base of the section to the late-middle Miocene. Magnetostratigraphic analysis constrains the entire section to the 12.4- to 6.5-Ma interval (Figure 2, Li et al., 2006). Deposits spanning this interval consist of three main sedimentary facies: fossilrich sandstone beds interpreted as fluvial channel deposits, pedogenized red mudstones interpreted as reflecting a floodplain environment, and calcareous gray-green mudstones reflecting as lacustrine phase (Li et al., 2006). Overall, the sequence is interpreted as reflecting a fluvio-lacustrine system with cyclic lake-expansion episodes (Figure 2).

\section{Methods}

One thousand eight hundred fifty rock samples were collected along a 92.5-m thick continuous part of the Tianshui section, with a sampling interval of $\sim 5 \mathrm{~cm}$. Our sampling profile starts at the top of the first thick sandstone layer in the log of $\mathrm{Li}$ et al. (2006, Figure 2), which is dated to $10.3 \mathrm{Ma}$ by magnetostratigraphy. Our sampling profile ends in the middle of a thick lacustrine member (about 80-m height in the log of $\mathrm{Li}$ et al., 2006), dated $\sim 8 \mathrm{Ma}$ by Li et al. (2006). This would give a $\sim 4.0-\mathrm{cm} / \mathrm{kyr}$ average accumulation rate for our $92.5-\mathrm{m}$ sampled interval. To investigate cyclicity in the section, we focused on two proxies: MS and $\mathrm{Rb} / \mathrm{Sr}$ ratios.

MS (quantified by $\kappa$; the volume susceptibility) of powdered samples was measured using a Bartington MS3 Magnetic Susceptibility System. The abundance of rubidium $(\mathrm{Rb})$ and strontium $(\mathrm{Sr})$ were measured with a Thermo Scientific Niton XL3t Handheld XRF (X-ray fluorescence) analyzer used in geochemistry mode (50and $10-\mathrm{kV}$ bean energies). The measurement time for each sample analysis was at least $50 \mathrm{~s}$. Both instruments are housed in the State Key Laboratory of Biogeology and Environmental Geology, China University of Geosciences (Wuhan).

$\mathrm{MS}$ and $\mathrm{Rb} / \mathrm{Sr}$ data series were prewhitened in Kaleidagraph software by subtracting $15 \%$ weighted averages in order to remove long-term trends. Then, a continuous wavelet transform was carried out using wavelet analysis (using a Morlet mother wavelet) to identify potential orbital cycles (see Torrence \& Compo, 1998 for wavelet analysis method). Based on evaluation of average accumulation rates and the expected ratios of Milankovitch frequencies, the dominant spectral components (eccentricity, obliquity, and precession cycles) in the data were extracted by using Gaussian band-pass filtering with AnalySeries 2.0.8 software (Paillard et al., 1996). The power spectra of the unturned (depth domain) and tuned (time domain) data were analyzed by the $2 \pi$-MultiTaper Method using the Singular Spectrum Analysis-MultiTaper Method Toolkit with robust red noise models used to ascertain the mean, 90, 95, and 99\% confidence levels (Mann \& Lees, 1996).

\section{Results}

The evolution of MS and $\mathrm{Rb} / \mathrm{Sr}$ data in the studied succession is strongly correlated with lithological variations (Figure 2). High values of MS and Rb/Sr correspond to red-brown mudstone layers, whereas low values correspond to grayish-green/gray-black mudstone, sandstone, and siltstone layers (Figure 2). 


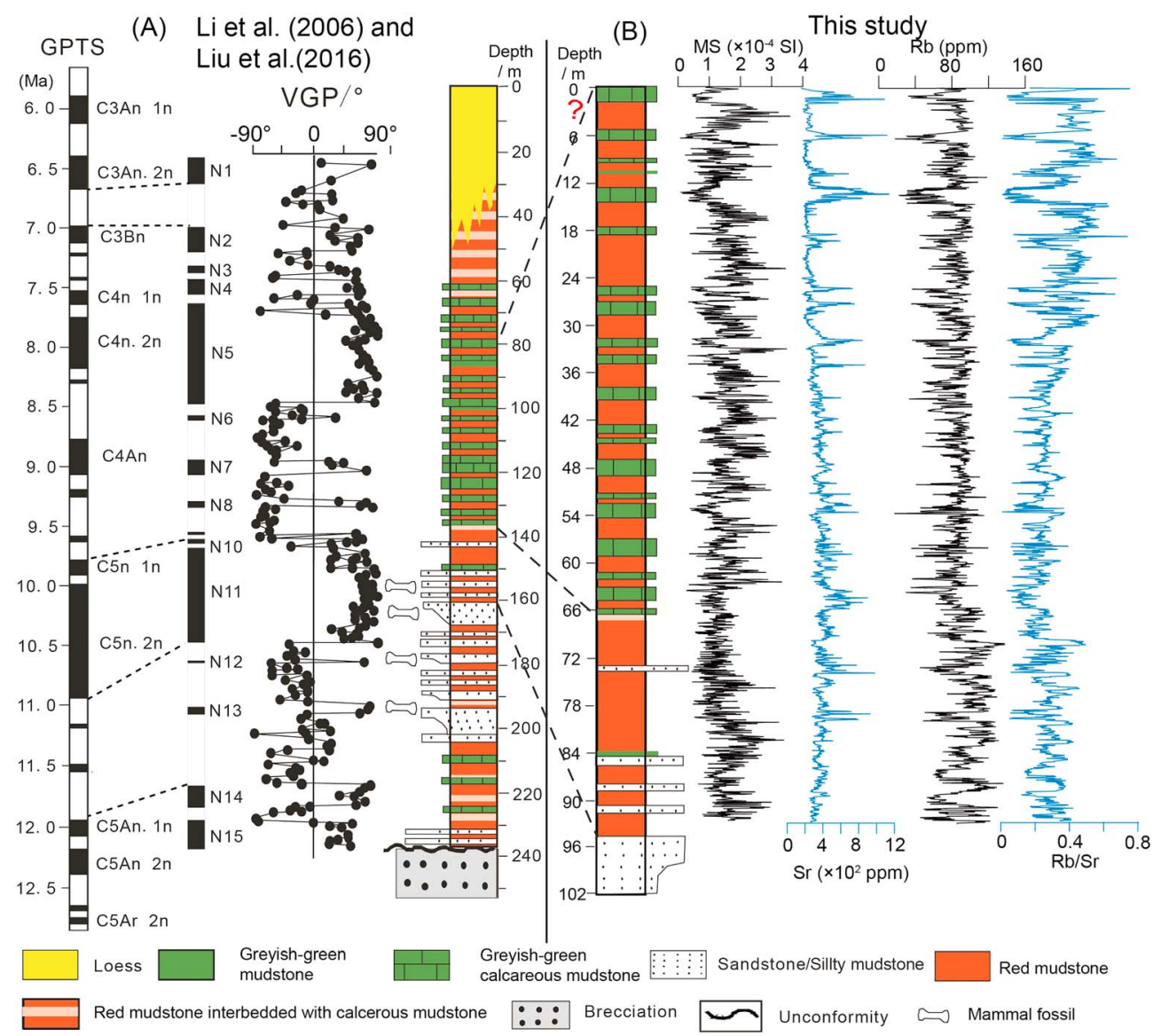

Figure 2. (a) Lithology and magnetic stratigraphy of the Yaodian section, Tianshui basin (from Li et al., 2006; Liu et al., 2016). (b) Magnetic susceptibility (MS), $\mathrm{Rb} / \mathrm{Sr}$ ratios, $\mathrm{Rb}$, and $\mathrm{Sr}$ content of the middle part in Yaodian site, with sampling resolution $\sim 5 \mathrm{~cm}$. The difference in sampling depth between Li et al. (2006) and our study is likely due to our more precise logging resolution $(0.05 \mathrm{~m})$.

The power spectrum of the $\mathrm{Rb} / \mathrm{Sr} \log$ series of the Tianshui basin shows significant peaks at 6.3-, 4.5-, 3.5-, 2.5-, 1.9- and 0.95-m wavelengths for our entire 92.5-m section (Figure 3a). Based on the paleomagnetic age constraints of $\mathrm{Li}$ et al. (2006) and evaluation of average accumulation rates (Figure 2), the 6.3-4.5 and 1.9 cycles can be assigned to short eccentricity and obliquity, respectively (Figure 3c). The MS series (0-92.5 m) show a similar set of significant peaks at $\sim 6.9-4.5,2.1$, and $0.85 \mathrm{~m}$ (Figure 3b). Similar to the $\mathrm{Rb} / \mathrm{Sr}$ series, these cycles can be assigned to short eccentricity, obliquity, and precession, respectively (Figure 3d). We tuned the $\mathrm{Rb} / \mathrm{Sr}$ and MS series to the $\sim 100$-kyr short-eccentricity cycles based on the recognition of $\sim 6.3-$ 4.5 , and $\sim 6.9-4.5 \mathrm{~m}$ cycles, respectively (Figure 3). Depth domain filtering of $\mathrm{Rb} / \mathrm{Sr}$ at $\sim 6.3-4.5 \mathrm{~m}$ and $\mathrm{MS}$ at $\sim 6.9-4.5 \mathrm{~m}$ is visible in the supporting information (see Figure DR2 in the supporting information). These depth cycles were then converted into time cycles to build an astronomical time scale based on the age boundaries of our sampling profile provided by $\mathrm{Li}$ et al. (2006). In total, we recognized twenty-two $\sim 100$-kyr cycles for each record, covering the time window from $\sim 10.25$ to $8 \mathrm{Ma}$ (Figure 4 ). This tuned age of $\sim 10.25-8 \mathrm{Ma}$ is in line with the paleomagnetic correlations of Li et al. (2006), with both our astronomical time scale and Li et al.'s magnetostratigraphic time scale dating the transition from sandy fluvio-lacustrine deposits to calcareous lake beds at $\sim 9.5 \mathrm{Ma}$ (Figure 2).

\section{Discussion}

\subsection{Synthesis}

In lacustrine layers, magnetic mineral dissolution can result in significant decreases in MS (Ao et al., 2010). MS orbital variations in our studied section can be interpreted as reflecting a balance between 

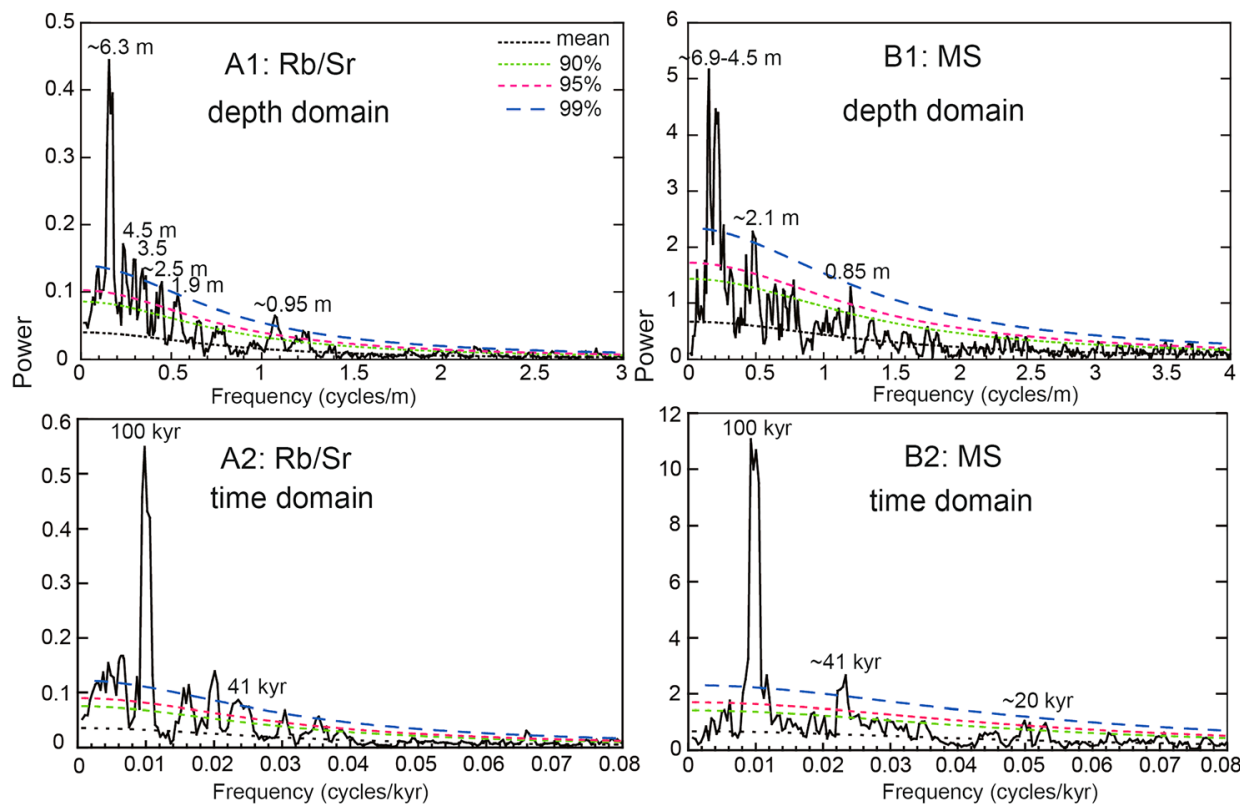

Figure 3. Spectral results of the measured MS and Rb/Sr ratios in Yaodian site, Tianshui basin. (a-d) The $2 \pi$ MultiTaper Method power spectrum of the $\mathrm{Rb} / \mathrm{Sr}$ and MS series in the depth and time domain after subtracting a $15 \%$ weighted average with robust red noise modeling, respectively. MS = magnetic susceptibility.

pedogenesis intensity (High MS, in paleosols) and dissolution (low MS, in lake beds). The behavior of the $\mathrm{Rb} / \mathrm{Sr}$ ratio has also been previously documented in Chinese Loess. $\mathrm{Rb}$ is a relatively stable element poorly affected by weather, whereas $\mathrm{Sr}$ is much more mobile and displays a strong affinity for carbonates (e.g., An et al., 2001); paleosols are leached in Sr by weathering processes and get much higher Rb/Sr ratios, whereas calcareous lake beds are enriched in $\mathrm{Sr}$ and display lower $\mathrm{Rb} / \mathrm{Sr}$ ratios (Figure 2). Collectively, both the variations of $\mathrm{MS}$ and $\mathrm{Rb} / \mathrm{Sr}$ values record lake level changes, linked to the regional hydrological cycle.

The reconstructed lake level fluctuations in the Tianshui basin covering the interval $\sim 10.25-8$ Ma fill an important temporal gap in our knowledge of East Asian orbital forcing between the cyclostratigraphic data of NE Tibet from lacustrine deposits in the Guide basin (14-10 Ma, Wang et al., 2018) and the Qaidam basin (8.5-7 Ma, Nie et al., 2017). Our record, combined with these others two, demonstrates the continuous prominence of $\sim 100$-kyr eccentricity forcing on lake expansion in NE Tibet for the interval 14-7 Ma. We do not reject the conclusion of Heitmann et al. (2017) suggesting that 41 -kyr obliquity forcing could have played a role during the late Miocene, but we argue that their study on a 12-m thick outcrop may not have had the resolution to capture the signal from longer, eccentricity cycles. A minor $41-k y r$ obliquity forcing was also recorded in the record of the Guide basin (Wang et al., 2018), and is also present in our record, though considerably weaker than eccentricity (Figures $3 a$ and $3 b$ ).

There are two main sources of atmospheric moisture that contribute to the hydrological budget of NE Tibet: winter, westerly derived rainfall, and the summer monsoon (Caves et al., 2015). Today, summer monsoonal rainfall contributes up to $60 \%$ of the hydrological budget, but the contribution of westerly derived moisture could have been more substantial in the past. Summer monsoonal rainfall intensity appears mainly controlled by 41-kyr obliquity cycles in Quaternary loess (Li et al., 2017). Westerly derived moisture penetration through time is poorly documented, but grain size and magnetic susceptibility studies in loess suggest that winter wind intensity is mainly controlled by alternating 400-, $100-$, and 41-kyr orbital controls over the Plio-Quaternary (Anwar et al., 2015; Ao et al., 2012; Li et al., 2017; Sun et al., 2006).

The dominant 100-kyr eccentricity control on lake expansion in NE Tibet for the 14-7 Ma interval is at odds with the dominant 41 -kyr obliquity forcing observed on summer rainfall intensity recorded in Quaternary loess (Li et al., 2017). This prompts two potential explanations: (1) either summer monsoonal penetration in North China was controlled by significantly different climatic mechanisms during the Miocene; (2) or this 

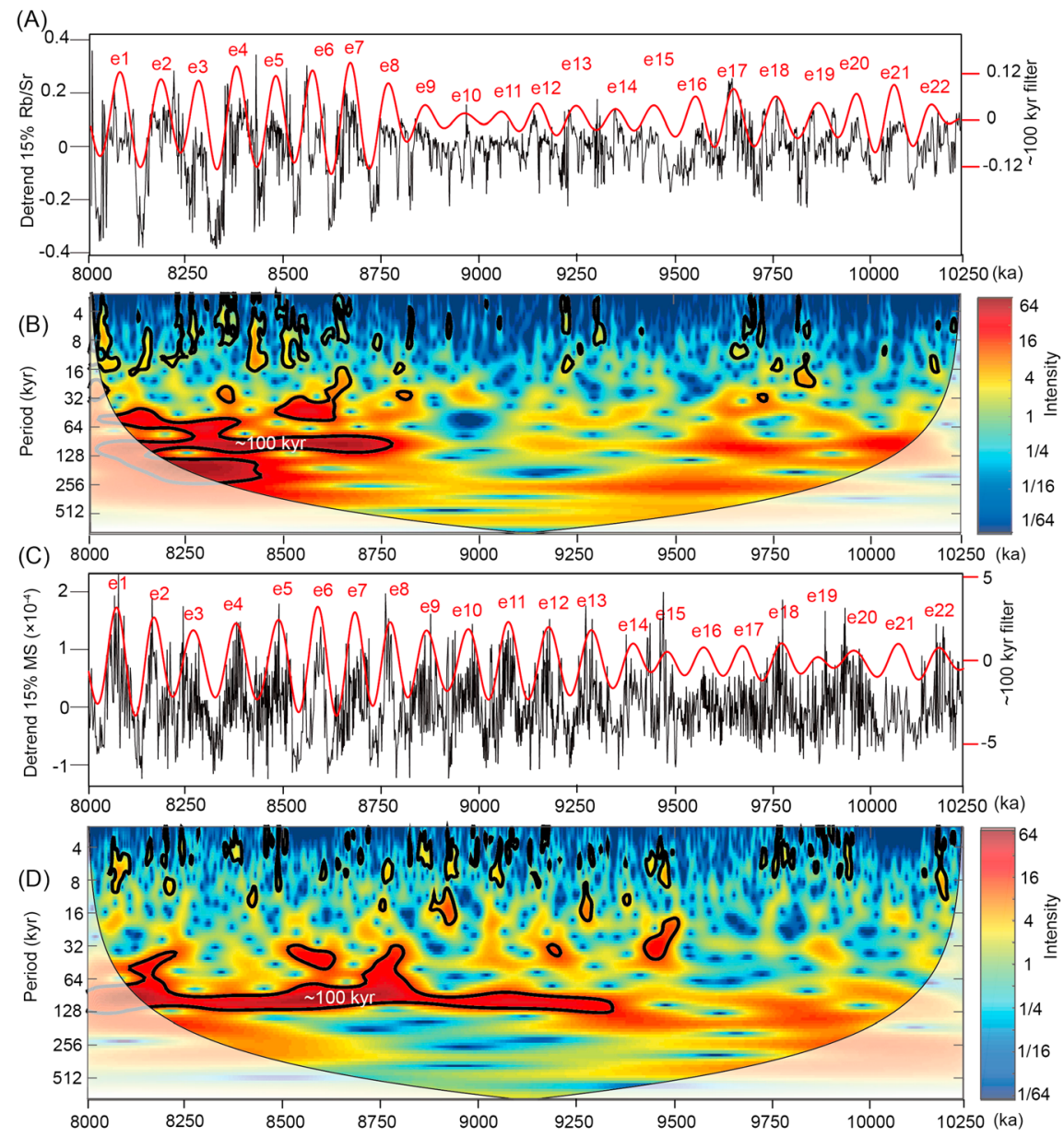

Figure 4. (a) Tuned $\mathrm{Rb} / \mathrm{Sr}$ series after subtracting a $15 \%$ weighted average with its $~ 100$-kyr filter output (red curve, $0.01 \pm$ 0.003 cycles/kyr). (b) Wavelet analysis of the tuned $\mathrm{Rb} / \mathrm{Sr}$ series. (c) The tuned MS series after subtracting a 15\% weighted average with its $\sim 100$-kyr filter output (red curve, $0.01 \pm 0.003$ cycles/kyr). (d) Wavelet analysis of the tuned MS series. e = short eccentricity; MS = magnetic susceptibility.

100-kyr eccentricity control reflects a bigger penetration of westerly derived moisture into North China during the period. In the following two subsections, we explore these alternative explanations.

\subsection{A Different Control on Summer Monsoonal Intensity?}

The 13.9- to 7-Ma interval is a period of long-term cooling during which the Northern Hemisphere was mostly free of ice, and the Antarctic ice sheet was smaller but more dynamic than today and experienced regular episodes of expansion and waning (de Vleeschouwer et al., 2017; Herbert et al., 2016). Nie et al. (2017) linked the dominant $\sim 100 \mathrm{kyr}$ cycles recorded in the Miocene Qaidam basin lake expansion record to insolation-driven Antarctic ice sheet forcing on monsoonal intensity and proposed two potential mechanisms: (1) periodic advances and retreats of East Asian coastlines associated with significant eustatic variations driven by the waning and waxing of ice sheets could have impacted the availability of moisture along the pathway of EASM winds; (2) periodic expansion of the Antarctic ice sheet reduced SST in tropical Pacific Ocean and could have impacted evaporation and moisture availability in the equatorial Pacific and weakened cross-equatorial pressure gradient and amount of latent heat release, resulting in a dampening of monsoonal intensity and moisture transport (Ao et al., 2016; Clemens et al., 2008).

The teleconnection between Antarctic ice sheet expansion and equatorial Pacific temperatures is not straightforward. The expansion of Antarctica ice sheets after 13.9 Ma (Holbourn et al., 2005) might have resulted in enhanced variability in intermediate and deep water production in the Southern Ocean and generally improved the Pacific ventilation that would have caused a strengthening of the Pacific 


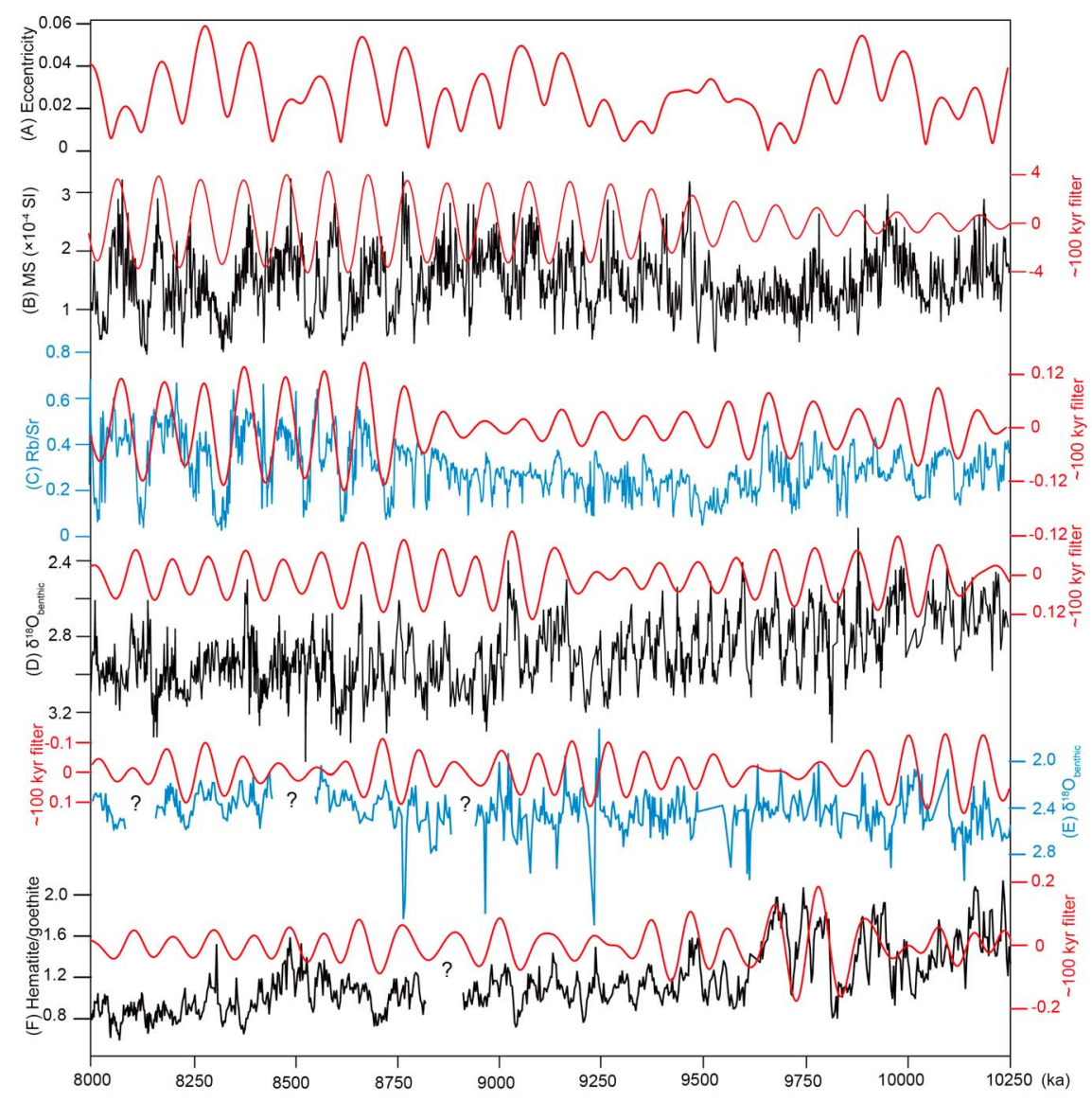

Figure 5. Spectral analysis from the Tianshui basin in NE Tibet (this study), and comparison with other climatic records over the interval 10.25-8 Ma. (a) Calculated eccentricity curve (Laskar et al., 2004). (b) MS data in Tianshui basin with its 100-kyr filter output (red curve, $0.01 \pm 0.003$ cycles/kyr). (c) $\mathrm{Rb} / \mathrm{Sr}$ data in Tianshui basin with its 100-kyr filter (red curve, $0.01 \pm 0.003$ cycles/kyr). (d) Benthic foraminifer oxygen isotope records from the ODP Site 1146 in South China Sea with its 100-kyr filter (red curve, $0.01 \pm 0.003$ cycles/kyr; Holbourn et al., 2018). (e) Benthic foraminifer oxygen isotope records from the ODP Site 1085 in SE Atlantic with its 100-kyr filter (red curve, $0.01 \pm 0.003$ cycles/kyr; Westerhold et al., 2005). (f) Hematite/goethite ratios from the ODP Site 1148 in the northern South China Sea with its 100-kyr filter (red curve, $0.01 \pm 0.003$ cycles/kyr; Clift, 2006). MS = magnetic susceptibility.

meridional overturning circulation (Holbourn, Kuhnt, Frank, et al., 2013). Strengthened Pacific meridional overturning circulation would have increased upwelling in the North Pacific, resulting in lower SSTs and reduced air temperatures and precipitation rates over adjacent land masses (Melles et al., 2012). This ocean circulation response to Antarctica ice sheet could have been the main driver of monsoonal intensity during this period.

Spectral analysis of benthic foraminifer oxygen isotope records in the South China Sea, close to the source of EASM moisture sources, shows dominant 100-kyr eccentricity cycles from 15 to $5.5 \mathrm{Ma}$, except for very short intervals showing the prominent obliquity cycles ( 14.6-14.1, 9.8-9.2, and 7.7-7.2 Ma; Holbourn, Kuhnt, Clemens, et al., 2013; Holbourn et al., 2018). Our spectral analysis of MS and Rb/Sr also show a relatively low strength of eccentricity from $\sim 9.8$ to $9.2 \mathrm{Ma}$, in agreement with the South China Sea record (Figure 5). A similar forcing is found in the hematite/goethite ratio in the South China Sea (Clift, 2006; Figure 5f). These records show a dominant $~ 100$-kyr eccentricity forcing on regional climate in the moisture source areas of the EASM and suggest that the forcing observed in Miocene Chinese lake expansions could be directly related to EASM variations.

\subsection{Higher Westerly Derived Moisture Penetration During the Miocene?}

The Qaidam, Guide, and Tuanshui basins are today all located on the pathway of winter westerlies (Caves et al., 2015; Figure 1). East of the Qaidam basin, climatic model studies reveal that more than $60 \%$ of 
moisture that reaches Central Asia today is transported by the westerlies (Sato et al., 2007; Yatagai \& Yasunari, 1998). During past intervals of weaker monsoon activity, westerly derived moisture from the Northern Atlantic Ocean and the Mediterranean Sea may have been a more important source of the precipitation in NE Tibet (Caves et al., 2015). Bougeois et al. (2018) have suggested that the uplift of the Tianshan and Pamir plateau after 25 Ma was important enough to shield moisture transportation by westerlies into central Asia. However, a narrow water-vapor channel between the Tianshan and Pamir highlands might have persisted until $\sim 7$ Ma (Sun et al., 2017), enhancing moisture transport from the Paratethys region and the Atlantic Ocean to the Tarim basin, and potentially reaching North Tibet (Chang et al., 2013). Northeastern Tibetan basins might have been shielded from dominant westerly brought moisture only recently, after late Miocene uplift episodes of the numerous local mountain ranges (Lease et al., 2012).

Middle Miocene lake expansions in southeast Kazakhstan, on the westerly wind pathway and beyond the EASM effect, have been shown to be dominantly controlled by eccentricity (Voigt et al., 2017). Similarly, middle-late Miocene lacustrine expansions in the circum-Mediterranean region have been shown to correlate with 100- and 400-kyr eccentricity maxima (Abels et al., 2010; Valero et al., 2014). The similarity between these records and our results suggests that westerly derived moisture supply could have been the dominant player in middle to late Miocene lake expansions in North Tibet. Orbital changes in the strength of the westerly winds are commonly related to the meridional temperature gradient and variations of the Atlantic meridional overturning circulation (Holbourn, Kuhnt, Frank, et al., 2013; Sun et al., 2011). A 100-kyr eccentricity control on Atlantic temperature (Figure 5e) and the Atlantic meridional overturning circulation during this period also require important climatic teleconnections between the Southern Hemisphere and the Northern Hemisphere, because very little ice existed in the Northern Hemisphere before $7 \mathrm{Ma}$ (Stein et al., 2016). The same mechanisms that affected SST in the equatorial Pacific might have been at play in the Atlantic Ocean.

\section{Conclusion}

New MS and Rb/Sr data from a high-resolution lacustrine record of the Tianshui basin, combined with previously published cyclostratigraphic records from North Tibet, show that regional lake expansion cycles over the 14- to 7-Ma interval have been consistently dominated by 100-kyr orbital forcing. Evidence for strong $\sim 100$ kyr cycles emphasizes a significant forcing of the North China hydrological cycle by Antarctic ice sheet variations during the middle to late Miocene. It is yet unclear if this forcing operated via modulation of EASM intensity or modulation of westerly derived moisture supply. Regardless of the exact nature of the main source of precipitation in North Tibet at that time, these results highlight the existence of a strong teleconnection between Antarctic ice sheet spreading and Northern Hemisphere climate, affecting the most continental areas of central Asia.

\section{Acknowledgments}

We thank Mengyang Hou for his assistance with field sampling. We also thank Jiangming Shen for his help in experiment. This work was supported by the National Natural Science Foundation of China (41772029), Natural Science Foundation for Distinguished Young Scholars of Hubei Province of China (2016CFA051), the Program of Introducing Talents of Discipline to Universities (B14031 and B08030), and the Fundamental Research Funds for the Central Universities, China University of Geosciences (CUGCJ1703 and CUGQYZX1705). Cyclostratigraphic data (MS and $\mathrm{Rb} / \mathrm{Sr}$ series) are available in the supporting information (https:// doi.org/10.1029/2019GL082283).

\section{References}

Abels, H. A., Aziz, H. A., Krijgsman, W., Smeets, S. J. B., \& Hilgen, F. J. (2010). Long-period eccentricity control on sedimentary sequences in the continental Madrid Basin (middle Miocene, Spain). Earth and Planetary Science Letters, 289(1-2), 220-231. https://doi.org/ 10.1016/j.epsl.2009.11.011

An, Z., Kutzbach, J. E., Prell, W. L., \& Porter, S. C. (2001). Evolution of Asian monsoons and phased uplift of the Himalaya-Tibetan plateau since Late Miocene times. Nature, 411(6833), 62-66.

Anwar, T., Kravchinsky, V. A., \& Zhang, R. (2015). Magneto- and cyclostratigraphy in the red clay sequence: New age model and paleoclimatic implication for the eastern Chinese Loess Plateau. Journal of Geophysical Research: Solid Earth, 120, 33-48. https://doi.org/ 10.1002/2015JB012132

Ao, H., Dekkers, M. J., Qin, L., \& Xiao, G. (2011). An updated astronomical timescale for the Plio-Pleistocene deposits from South China Sea and new insights into Asian monsoon evolution. Quaternary Science Reviews, 30(13-14), 1560-1575. https://doi.org/10.1016/j. quascirev.2011.04.009

Ao, H., Dekkers, M. J., Xiao, G., Yang, X., Qin, L., Liu, X., et al. (2012). Different orbital rhythms in the Asian summer monsoon records from North and South China during the Pleistocene. Global and Planetary Change, 80, 51-60.

Ao, H., Deng, C., Dekkers, M. J., \& Liu, Q. (2010). Magnetic mineral dissolution in Pleistocene fluvio-lacustrine sediments, Nihewan basin (North China). Earth and Planetary Science Letters, 292(1-2), 191-200. https://doi.org/10.1016/j.epsl.2010.01.035

Ao, H., Roberts, A. P., Dekkers, M. J., Liu, X., Rohling, E. J., Shi, Z., et al. (2016). Late Miocene-Pliocene Asian monsoon intensification linked to Antarctic ice-sheet growth. Earth and Planetary Science Letters, 444, 75-87. https://doi.org/10.1016/j. epsl.2016.03.028

Bougeois, L., Dupont-Nivet, G., de Rafélis, M., Tindall, J. C., Proust, J.-N., Reichart, G.-J., et al. (2018). Asian monsoons and aridification response to Paleogene sea retreat and Neogene westerly shielding indicated by seasonality in Paratethys oysters. Earth and Planetary Science Letters, 485, 99-110. https://doi.org/10.1016/j.epsl.2017.12.036 
Caley, T., Malaizé, B., Ducassou, E., Marieu, V., Revel, M., Wainer, K., et al. (2011). Orbital timing of the Indian, East Asian and African boreal monsoons and the concept of a 'global monsoon'. Quaternary Science Reviews, 30(25-26), 3705-3715. https://doi.org/10.1016/j. quascirev.2011.09.015

Caley, T., Roche, D. M., \& Renssen, H. (2014). Orbital Asian summer monsoon dynamics revealed using an isotope-enabled global climate model. Nature Communications, 5(1), 5371. https://doi.org/10.1038/ncomms6371

Caves, J. K., Winnick, M. J., Graham, S. A., Sjostrom, D. J., Mulch, A., \& Chamberlain, C. P. (2015). Role of the westerlies in Central Asia climate over the Cenozoic. Earth and Planetary Science Letters, 428, 33-43. https://doi.org/10.1016/j.epsl.2015.07.023

Chang, H., An, Z., Wu, F., Jin, Z., Liu, W., \& Song, Y. (2013). A Rb/Sr record of the weathering response to environmental changes in westerly winds across the Tarim Basin in the late Miocene to the early Pleistocene. Palaeogeography, Palaeoclimatology, Palaeoecology, 386, 364-373. https://doi.org/10.1016/j.palaeo.2013.06.006

Cheng, H., Edwards, R. L., Sinha, A., Spotl, C., Yi, L., Chen, S., et al. (2016). The Asian monsoon over the past 640,000 years and ice age terminations. Nature, 534(7609), 640-646. https://doi.org/10.1038/nature18591

Clemens, S. C., Prell, W. L., Sun, Y., Liu, Z., \& Chen, G. (2008). Southern Hemisphere forcing of Pliocene $\delta 180$ and the evolution of IndoAsian monsoons. Paleoceanography, 23, PA4210. https://doi.org/10.1029/2008PA001638

Clift, P. D. (2006). Controls on the erosion of Cenozoic Asia and the flux of clastic sediment to the ocean. Earth and Planetary Science Letters, 241(3-4), 571-580. https://doi.org/10.1016/j.epsl.2005.11.028

Craddock, W., Kirby, E., \& Zhang, H. (2011). Late Miocene-Pliocene range growth in the interior of the northeastern Tibetan plateau. Lithosphere, 3(6), 420-438. https://doi.org/10.1130/L159.1

de Vleeschouwer, D., Vahlenkamp, M., Crucifix, M., \& Pälike, H. (2017). Alternating Southern and Northern Hemisphere climate response to astronomical forcing during the past 35 m.y. Geology, 45, 38,663-38,661.

Ding, Z. L., Derbyshire, E., Yang, S. L., Yu, Z. W., Xiong, S. F., \& Liu, T. S. (2002). Stacked 2.6-Ma grain size record from the Chinese loess based on five sections and correlation with the deep-sea $\delta 180$ record. Paleoceanography, 17(3), 1033. https://doi.org/10.1029/ 2001PA000725

Heitmann, E. O., Ji, S., Nie, J., \& Breecker, D. O. (2017). Orbitally-paced variations of water availability in the SE Asian monsoon region following the Miocene climate transition. Earth and Planetary Science Letters, 474, 272-282. https://doi.org/10.1016/j.epsl.2017.06.006

Herbert, T. D., Lawrence, K. T., Tzanova, A., Peterson, L. C., Caballero-Gill, R., \& Kelly, C. S. (2016). Late Miocene global cooling and the rise of modern ecosystems. Nature Geoscience, 9(11), 843-847. https://doi.org/10.1038/ngeo2813

Holbourn, A., Kuhnt, W., Clemens, S., Prell, W., \& Andersen, N. (2013). Middle to late Miocene stepwise climate cooling: Evidence from a high-resolution deep water isotope curve spanning 8 million years. Paleoceanography, 28, 688-699. https://doi.org/10.1002/ 2013PA002538

Holbourn, A., Kuhnt, W., Frank, M., \& Haley, B. A. (2013). Changes in Pacific Ocean circulation following the Miocene onset of permanent Antarctic ice cover. Earth and Planetary Science Letters, 365, 38-50. https://doi.org/10.1016/j.epsl.2013.01.020

Holbourn, A., Kuhnt, W., Schulz, M., \& Erlenkeuser, H. (2005). Impacts of orbital forcing and atmospheric carbon dioxide on Miocene icesheet expansion. Nature, 438(7067), 483-487. https://doi.org/10.1038/nature04123

Holbourn, A. E., Kuhnt, W., Clemens, S. C., Kochhann, K. G. D., Johnck, J., Lubbers, J., \& Andersen, N. (2018). Late Miocene climate cooling and intensification of southeast Asian winter monsoon. Nature Communications, 9(1), 1584. https://doi.org/10.1038/s41467-018 03950-1

Laskar, J., Robutel, P., Joutel, F., Gastineau, M., Correia, A., \& Levrard, B. (2004). A long-term numerical solution for the insolation quantities of the Earth. Astronomy \& Astrophysics, 428(1), 261-285. https://doi.org/10.1051/0004-6361:20041335

Lease, R. O. (2014). Cenozoic mountain building on the northeastern Tibetan plateau. Special Paper of the Geological Society of America, 507, 115-127. https://doi.org/10.1130/2014.2507(06)

Lease, R. O., Burbank, D. W., Gehrels, G. E., Wang, Z., \& Yuan, D. (2007). Signatures of mountain building: Detrital zircon U/Pb ages from northeastern Tibet. Geology, 35(3), 239-242. https://doi.org/10.1130/G23057A.1

Lease, R. O., Burbank, D. W., Hough, B., Wang, Z., \& Yuan, D. (2012). Pulsed Miocene range growth in northeastern Tibet: Insights from Xunhua basin magnetostratigraphy and provenance. Geological Society of America Bulletin, 124(5-6), 657-677. https://doi.org/10.1130/ B30524.1

Li, J., Zhang, J., Song, C., Zhao, Z., Zhang, Y., Wang, X., et al. (2006). Miocene Bahean stratigraphy in the Longzhong basin, northern central China and its implications in environmental change. Science China: Earth Sciences, 49(12), 1270-1279. https://doi.org/10.1007/ s11430-006-2057-y

Li, T., Liu, F., Abels, H. A., You, C.-F., Zhang, Z., Chen, J., et al. (2017). Continued obliquity pacing of East Asian summer precipitation after the mid-Pleistocene transition. Earth and Planetary Science Letters, 457, 181-190. https://doi.org/10.1016/j.epsl.2016.09.045

Lisiecki, L. E., \& Raymo, M. E. (2005). A Pliocene-Pleistocene stack of 57 globally distributed benthic $\delta^{18}$ O records. Paleoceanography, 20, PA1003. https://doi.org/10.1029/2004PA001071

Liu, J., Li, J. J., Song, C. H., Yu, H., Peng, T. J., Hui, Z. C., \& Ye, X. Y. (2016). Palynological evidence for late Miocene stepwise aridification on the northeastern Tibetan plateau. Climate of the Past, 12(7), 1473-1484. https://doi.org/10.5194/cp-12-1473-2016

Mann, M. E., \& Lees, J. M. (1996). Robust estimation of background noise and signal detection in climatic time series. Climatic Change, 33(3), 409-445. https://doi.org/10.1007/BF00142586

Melles, M., Brighamgrette, J., Minyuk, P. S., Nowaczyk, N. R., Wennrich, V., Deconto, R. M., et al. (2012). 2.8 million years of Arctic climate change from Lake El'gygytgyn, NE Russia. Science, 337(6092), 315-320. https://doi.org/10.1126/science.1222135

Nakagawa, T., Okuda, M., Yonenobu, H., Miyoshi, N., Fujiki, T., Gotanda, K., et al. (2008). Regulation of the monsoon climate by two different orbital rhythms and forcing mechanisms. Geology, 36(6), 491-494. https://doi.org/10.1130/G24586A.1

Nie, J., Garzione, C., Su, Q., Liu, Q., Zhang, R., Heslop, D., et al. (2017). Dominant 100,000-year precipitation cyclicity in a late Miocene lake from northeast Tibet. Science Advances, 3, e1600762.

Nie, J., King, J. W., \& Fang, X. (2008). Tibetan uplift intensified the 400 k.y. signal in paleoclimate records at 4 Ma. Geological Society of America Bulletin, 120(9-10), 1338-1344. https://doi.org/10.1130/B26349.1

Paillard, D., Labeyrie, L., \& Yiou, P. (1996). Macintosh program performs time-series analysis. Eos, Transactions American Geophysical Union, 77(39), 379-379. https://doi.org/10.1029/96EO00259

Pollard, D., \& DeConto, R. M. (2009). Modelling west Antarctic ice sheet growth and collapse through the past five million years. Nature, 458(7236), 329-332. https://doi.org/10.1038/nature07809

Qu, Y. P., \& Cai, T. L. (1984). The Tertiary in Gansu Province [in Chinese]. Gansu Geol, 2, 1-40.

Sato, T., Kimura, F., \& Kitoh, A. (2007). Projection of global warming onto regional precipitation over Mongolia using a regional climate model. Journal of Hydrology, 333(1), 144-154. https://doi.org/10.1016/j.jhydrol.2006.07.023 
Stein, R., Fahl, K., Schreck, M., Knorr, G., Niessen, F., Forwick, M., et al. (2016). Evidence for ice-free summers in the late Miocene central Arctic Ocean. Nature Communications, 7(1), 11148. https://doi.org/10.1038/ncomms11148

Sun, J., Liu, W., Liu, Z., Deng, T., Windley, B. F., \& Fu, B. (2017). Extreme aridification since the beginning of the Pliocene in the Tarim Basin, western China. Palaeogeography, Palaeoclimatology, Palaeoecology, 485, 189-200. https://doi.org/10.1016/j.palaeo.2017.06.012

Sun, Y., Clemens, S. C., An, Z., \& Yu, Z. (2006). Astronomical timescale and palaeoclimatic implication of stacked 3.6-Myr monsoon records from the Chinese loess plateau. Quaternary Science Reviews, 25(1-2), 33-48. https://doi.org/10.1016/j.quascirev.2005.07.005

Sun, Y., Clemens, S. C., Morrill, C., Lin, X., Wang, X., \& An, Z. (2011). Influence of Atlantic meridional overturning circulation on the East Asian winter monsoon. Nature Geoscience, 5, 46-49.

Torrence, C., \& Compo, G. P. (1998). A practical guide to wavelet analysis. Bulletin of the American Meteorological Society, 79(1), 61-78.

Valero, L., Garcés, M., Cabrera, L., Costa, E., \& Sáez, A. (2014). 20 Myr of eccentricity paced lacustrine cycles in the Cenozoic Ebro basin. Earth and Planetary Science Letters, 408, 183-193. https://doi.org/10.1016/j.epsl.2014.10.007

Voigt, S., Weber, Y., Frisch, K., Bartenstein, A., Hellwig, A., Petschick, R., et al. (2017). Climatically forced moisture supply, sediment flux and pedogenesis in Miocene mudflat deposits of south-east Kazakhstan, Central Asia. The Depositional Record, 3(2), 209-232. https:// doi.org/10.1002/dep2.34

Wang, X., Zattin, M., Li, J., Song, C., Peng, T., Liu, S., \& Liu, B. (2011). Eocene to Pliocene exhumation history of the Tianshui-Huicheng region determined by Apatite fission track thermochronology: Implications for evolution of the northeastern Tibetan plateau margin Journal of Asian Earth Sciences, 42(1-2), 97-110. https://doi.org/10.1016/j.jseaes.2011.04.012

Wang, Y., Cheng, H., Edwards, R. L., Kong, X., Shao, X., Chen, S., et al. (2008). Millennial- and orbital-scale changes in the East Asian monsoon over the past 224,000 years. Nature, 451(7182), 1090-1093. https://doi.org/10.1038/nature06692

Wang, Z., Shen, Y., Licht, A., \& Huang, C. (2018). Cyclostratigraphy and magnetostratigraphy of the middle Miocene Ashigong formation, Guide basin, China, and its implications for the paleoclimatic evolution of NE Tibet. Paleoceanography and Paleoclimatology, 33, 1066-1085. https://doi.org/10.1029/2018PA003409

Wang, Z. X., Liang, M. Y., Sun, Y. Q., \& Dai, G. W. (2017). Cenozoic tectonic and geomorphic evolution of the Longxi region in northeastern Tibetan plateau interpreted from detrital zircon. Science China Earth Sciences, 60(2), 256-267. https://doi.org/10.1007/s11430-016-5247-

Weber, S., \& Tuenter, E. (2011). The impact of varying ice sheets and greenhouse gases on the intensity and timing of boreal summer monsoons. Quaternary Science Reviews, 30(3-4), 469-479. https://doi.org/10.1016/j.quascirev.2010.12.009

Westerhold, T., Bickert, T., \& Röhl, U. (2005). Middle to late Miocene oxygen isotope stratigraphy of ODP site 1085 (SE Atlantic): New constrains on Miocene climate variability and sea-level fluctuations. Palaeogeography, Palaeoclimatology, Palaeoecology, 217(3-4), 205-222. https://doi.org/10.1016/j.palaeo.2004.12.001

Yatagai, A., \& Yasunari, T. (1998). Variation of summer water vapor transport related to precipitation over and around the arid region in the interior of the Eurasian continent. Journal of the Meteorological Society of Japan. Series II, 76(5), 799-815. https://doi.org/10.2151/ jmsj1965.76.5_799

Yuan, B. Y., Guo, Z. T., Hao, Q. Z., Peng, S. Z., Qiao, Y. S., Wu, H. B., et al. (2007). Cenozoic evolution of geomorphic and sedimentary environments in the Tianshui-Qin'an regions [in Chinese]. Quaternary Science, 27, 161-171.

Zhang, H.-P., Craddock, W. H., Lease, R. O., Wang, W.-t., Yuan, D.-Y., Zhang, P.-Z., et al. (2012). Magnetostratigraphy of the Neogene Chaka basin and its implications for mountain building processes in the north-eastern Tibetan plateau. Basin Research, 24(1), 31-50. https://doi.org/10.1111/j.1365-2117.2011.00512.x

Zheng, D., Zhang, P.-Z., Wan, J., Yuan, D., Li, C., Yin, G., et al. (2006). Rapid exhumation at 8 Ma on the Liupan Shan thrust fault from apatite fission-track thermochronology: Implications for growth of the northeastern Tibetan plateau margin. Earth and Planetary Science Letters, 248(1-2), 198-208. https://doi.org/10.1016/j.epsl.2006.05.023 